\title{
Point of care ultrasound - the noninvasive evaluation of hemodynamic status
}

\author{
T Zawada*, A Wieczorek, P Garba \\ From ESICM LIVES 2015 \\ Berlin, Germany. 3-7 October 2015
}

\section{Introduction}

Echocardiography(ECHO) is a useful diagnostic and monitoring tool. It allows to perform repetitive hemodynamic and functional assessment over a period of minutes, hours or days in the same patients to guide applied therapy. ECHO has been performed by our medical staff for 3 years and since then we have been observing reduced number of using invasive monitoring in our ICU.

\section{Objectives}

The aim of the study was to analyze impact on diagnosis, decision making and management based on data received from invasive monitoring vs. echocardiography.

\section{Methods}

Data from 2 years before and 2 years after implementing a routine echocardiography to provide hemodynamic assessments have been compared and statistical analysis has been made.

\section{Results}

\section{Conclusions}

Echocardiography could be a useful method to asses patients hemodynamic status and to plan fluid or inotropic therapy. In our investigation ECHO allowed to reduce usage of fluids and

did not influence on mean time of mechanical ventilation and mortality.

\section{Grant Acknowledgment}

ICU Staff.
Table 1. Results

\begin{tabular}{|c|c|c|c|}
\hline & 2011-2012 & 2013-2014 & $p$ \\
\hline Number of hospitalized patients & 666 & 648 & NS \\
\hline SAPS2 & 52.6 & 53 & NS \\
\hline Mean age of hospitalized patients & 61 & 62 & NS \\
\hline $\begin{array}{l}\text { Mean time of ICU hospitalization } \\
\text { (days) }\end{array}$ & 7.1 & 8.0 & NS \\
\hline Infections rate/1000 & 34.3 & 55.6 & NS \\
\hline $\begin{array}{l}\text { Mean time of mechanical } \\
\text { ventilation }\end{array}$ & 6.2 & 8.3 & NS \\
\hline COST OF COLLOIDS per year (euro) & 6110 & 2755 & $p<0.05$ \\
\hline $\begin{array}{l}\text { COST OF CRISTALLOIDS per year } \\
\text { (euro) }\end{array}$ & 2985 & 4118.5 & $p<0.05$ \\
\hline Mortality & $36.5 \%$ & $36 \%$ & NS \\
\hline
\end{tabular}

\section{References}

1. Poter TR, Shillcutt SK, Adams MS, Desjardins G, Glas KE, Olson JJ, et al: Guidelines for the Use of Echocardiography as a Monitor for Therapeutic Intervention in Adults: A Report from the American Society of Echocardiography. J Am Soc Echocardiogr 2015, 28(1):40-56.

2. Roscoe A, Strang T: Echocardiography in intensive care. Contin EduC Anaesth Crit Care Pain 2008, 8(2):46-49.

3. Charron C, Caille V, Jardin F, Vieillard-Baron A: Echocardiographic measurement of fluid responsiveness. Curr Opin Crit Care 2006, 12(3):249-254

4. Repessé X, Charron C, Vieillard-Baron A: Intensive care ultrasound: V. Goaldirected echocardiography. Ann Am Thorac Soc 2014, 11(1):122-128.

5. Charron C, Repessé X, Bodson L, Au SM, Vieillard-Baron A: Ten good reasons why everybody can and should perform cardiac ultrasound in the ICU. Anaesthesiol Intensive Ther 2014, 46(5):319-322.

\section{doi:10.1186/2197-425X-3-S1-A543}

Cite this article as: Zawada et al:: Point of care ultrasound - the noninvasive evaluation of hemodynamic status. Intensive Care Medicine Experimental 2015 3(Suppl 1):A543. 